\title{
Exposure to caspofungin activates Cap and Hog pathways in Candida albicans
}

\author{
JUDY KELLY*, RAYMOND ROWAN*, MALACHY MCCANN† \& KEVIN KAVANAGH* \\ *Medical Mycology Unit, Department of Biology, National Instiute for Cellular Biotechnology, and †Department of Chemistry, \\ NUI Maynooth, Co. Kildare, Ireland
}

Caspofungin is a member of the echinocandin group of antifungals and inhibits the activity of $\beta$-glucan synthase thus disrupting cell wall formation and function. While the potent antifungal activity of this agent is well established, this paper analyzed the response of Candida albicans to caspofungin. Exposure of yeast cells to $0.19 \mu \mathrm{g} / \mathrm{ml}$ caspofungin for 1 to $4 \mathrm{~h}$ induced nuclear translocation of Cap1p which was confirmed by Western blotting and confocal microscopy. Caspofungin-treated cells demonstrated increased expression of a number of genes associated with the oxidative stress response, including glutathione reductase (GLR1), mitochondrial processing protease (MAS1) and manganese-superoxide dismutase (SOD2) as well as elevated activity of glutathione reductase and superoxide dismutase. Caspofungin treatment also leads to the nuclear localization of Hog $1 \mathrm{p}$ as visualized by Western blot using anti-phospho-p38 MAPK (Thr180/Tyr182) antibody. This translocation event lead to increased mRNA levels of catalase (CAT1) but not alkyl hydroperoxide reductase (AHP1). The activity of catalase was increased and reached a maximum at $2 \mathrm{~h}$. In addition, pre-exposure of $C$. albicans to hydrogen peroxide $(0.5 \mathrm{mM}, 60 \mathrm{~min})$ conferred an increased tolerance to caspofungin. The data presented here highlight the potent antifungal activity of caspofungin and demonstrate that upon exposure to this agent, $C$. albicans activates the Cap and Hog pathways in an attempt to limit the oxidative and osmotic stresses associated with this drug.

Keywords antifungal, Candida, caspofungin, oxidative stress in yeast, HOG1, Cap1p

\section{Introduction}

There has been a significant increase in the incidence of fungal infections with yeast of the genus Candida becoming the fourth most common cause of nosocomial bloodstream infections [1]. The echinocandins represent a novel class of anti-fungal agent which has been recently introduced into clinical practice. Unlike polyenes and azoles (that target ergosterol or the ergosterol biosynthetic pathway, respectively) echinocandins function by inhibiting the synthesis of $\beta-1,3-D$-glucan, an essential component of the fungal cell wall, resulting in osmotic lysis of the cell [2]. Caspofungin was the first member of the echinocandins

\footnotetext{
Received 10 June 2008; Received in final revised form 18 August 2008; Accepted 14 October 2008

Correspondence: Kevin Kavanagh, Medical Mycology Unit, NICB, Department of Biology, NUI Maynooth, Co. Kildare, Ireland. Tel:+ 353 1708 3859; Fax: +353 1 7083845; E-mail:kevin.kavanagh@ nuim.ie
}

(c) 2009 ISHAM to receive approval to be licensed for clinical use [2] and is marketed as Cancidas. Caspofungin has shown in vitro and in vivo activity against Candida and Aspergillus species [3-11]. The structure of caspofungin contains a long fatty acid side chain that allows intercalation in the bi-layer of the fungal cell membrane [12] where it may interact with $\beta$-1,3-D-glucan synthase. Caspofungin has an excellent safety profile and recent studies show it is as effective as, and usually better tolerated than, liposomal amphotericin B [8].

Yeast cells encounter a wide range of stresses during growth and, as a consequence, adaptation to stress including oxidative and osmotic stress is essential for continued survival and replication. A key regulator of oxidative stress tolerance in C. albicans is the Cap pathway. Cap1p transcriptional regulatory protein is a member of the basic region-leucine zipper (bZip) family [13]. Upon exposure to oxidative stress-inducing agents (such as hydrogen peroxide) Caplp translocates from the cytoplasm to the 
nucleus in C. albicans [14]. Once in the nucleus, Cap1p plays an important role as a transcription regulator, where it has been shown to control a range of target genes, including reductases, dehydrogenases, proteases, oxidoreductases, RNA helicases and transporters, indicative of the defensive role of Cap1p in tolerating oxidative stress through activation of multiple pathways [15].

The high osmolarity glycerol (HOG) mitogen-activated protein kinase (MAPK) pathway has also been shown to be involved in the cell's responses to oxidative [16] and osmotic [17] stresses. Upon exposure to oxidative or osmotic stress, a series of events leads to the phosphorylation of Hog $1 \mathrm{p}$ which translocates to the nucleus of the cell [18]. Upon localising to the nucleus, Hog $1 p$ controls the expression of numerous genes by regulating the activity of transcriptional activators and repressors [for review see 19].

This study examined the interaction of caspofungin with C. albicans and in particular examined the response of fungal cells to this agent. It was postulated that the activation of osmotic and oxidative stress responses could have implications for the response of this yeast to this agent in vivo.

\section{Materials and methods}

Yeast isolates and culture conditions

Candida albicans MEN (a clinical isolate, received from Dr D. Kerridge, Cambridge, UK) was used in this study. Cultures were grown in YEPD (yeast extract-peptone-Dglucose) broth (2\% (w/v) glucose (Sigma-Aldrich Chemical Co. Ltd, Dorset, UK), $2 \%$ (w/v) bacteriological peptone (Oxoid Ltd., Basingstoke, UK) and 1\% (w/v) yeast extract (Scharlau, Barcelona, Spain) at $30^{\circ} \mathrm{C}$ and $200 \mathrm{rpm}$ until the stationary phase (approx. $1 \times 10^{8}$ cells/ml) was achieved. Stocks were maintained on YEPD with the addition of $2 \%$ $(\mathrm{w} / \mathrm{v})$ agar (Scharlau), stored at $4^{\circ} \mathrm{C}$ and sub-cultured every 4-6 weeks.

\section{Extraction of cytoplasmic and nuclear proteins}

Stationary phase cells $\left(1 \times 10^{8}\right)$ were added to fresh YEPD medium $(50 \mathrm{ml})$ and grown to late exponential phase (approximately $8 \times 10^{6} / \mathrm{ml}$ ). Caspofungin (Merck \& Co. Inc., NJ, USA) $\left(\mathrm{MIC}_{90}, 0.19 \mu \mathrm{g} / \mathrm{ml}\right)$ or hydrogen peroxide (Sigma-Aldrich) $(0.5 \mathrm{mM})$ was added and the cultures were grown for a further $0.5,1,2$ or $4 \mathrm{~h}$. Cells ( $1 \mathrm{~g}$ wet weight) were resuspended in $4 \mathrm{ml}$ pre-treatment buffer $(50 \mathrm{mM}$ tris-HCl (pH 7.5) (Sigma-Aldrich), $10 \mathrm{mM}$ magnesium chloride (Sigma-Aldrich), 1 M sorbitol (Sigma-Aldrich), $60 \mathrm{mM}$ 2-mercaptoethanol (Sigma-Aldrich), $3 \mathrm{mg} / \mathrm{ml}$ dithiothreitol (DTT) (Sigma-Aldrich) and incubated at $30^{\circ} \mathrm{C}$ and $100 \mathrm{rpm}$ for $30 \mathrm{~min}$. Cells were harvested
(2056 $g$ for $5 \mathrm{~min}$ ) on a Beckmann GS-6 bench centrifuge and resuspended in $4 \mathrm{ml}$ digestion buffer $(50 \mathrm{mM}$ tris- $\mathrm{HCl}$ (pH 7.5), $10 \mathrm{mM}$ magnesium chloride, $1 \mathrm{M}$ sorbitol, $1 \mu \mathrm{l} / \mathrm{ml}$ 2-mercaptoethanol and 400 Units zymolase (Seikagaku Corporation, Tokyo, Japan) and incubated at $30^{\circ} \mathrm{C}$ with gentle shaking until spheroplasts were formed (40 min approx.). The cells were washed gently in $1 \mathrm{M}$ sorbitol and collected by centrifugation ( $425 \mathrm{~g}$ for $10 \mathrm{~min}$ ). Pellets were resuspended in $4 \mathrm{ml}$ Lysis Buffer A (18\% (w/v) ficoll PM400 (Sigma-Aldrich), $0.5 \mathrm{mM}$ magnesium chloride, 20 $\mathrm{mM}$ potassium phosphate (Sigma-Aldrich), $1 \mathrm{mg} / \mathrm{ml}$ pepstatin A (Sigma-Aldrich), $1 \mathrm{mg} / \mathrm{ml}$ aprotinin (SigmaAldrich), $1 \mathrm{mM}$ PMSF (Sigma-Aldrich), $50 \mathrm{mM}$ sodium pyrophosphate (Fluka, Biochemika, Germany), $50 \mathrm{mM}$ sodium fluoride (Fluka), $50 \mathrm{mM} \beta$-glycerol phosphate (Fluka) and $10 \mathrm{mM}$ sodium orthovandate (Sigma-Aldrich), pH 6.45). The suspension was homogenised for 5 minutes on ice. An equal volume (4 ml) of Lysis Buffer B was added (2.4 M sorbitol, $0.5 \mathrm{mM}$ magnesium chloride, $20 \mathrm{mM}$ potassium phosphate, $1 \mathrm{mg} / \mathrm{ml}$ pepstatin $\mathrm{A}, 1 \mathrm{mg} / \mathrm{ml}$ aprotinin, $1 \mathrm{mM}$ PMSF, $50 \mathrm{mM}$ sodium pyrophosphate, $50 \mathrm{mM}$ sodium flouride, $50 \mathrm{mM} \beta$-glycerol phosphate and $10 \mathrm{mM}$ sodium orthovandate, $\mathrm{pH}$ 6.45) and the mixture was homogenized for a further 5 minutes on ice. The lysate was spun at $2655 \mathrm{~g}$ for $10 \mathrm{~min}$ at $4^{\circ} \mathrm{C}$ (Eppendorf centrifuge 5417R). The pellets were discarded and the supernatants were transferred to a new tube and centrifuged at $17,950 \mathrm{~g}$ for $35 \mathrm{~min}$ at $4^{\circ} \mathrm{C}$. The resulting supernatants (cytoplasmic proteins) were stored at $-70^{\circ} \mathrm{C}$. The pellets (nuclear proteins) were resuspended in a 50:50 mixture of Lysis Buffer A: Lysis Buffer B and stored at $-70^{\circ} \mathrm{C}$. Protein concentration was determined using the Bradford reagent (Bio-Rad, Munich, Germany), with BSA (Sigma-Aldrich) as standard. In order to verify the successful isolation of nuclear protein, Western blot analysis on this fraction was performed using an antibody against proliferating cell nuclear antigen (Sigma-Aldrich) (data not presented).

\section{Electrophoresis and immunoblotting}

For Western blotting, the protein was transferred to a nitrocellulose membrane using a semi-dry blotter (Bio-Rad) at $18 \mathrm{~V}$ for $20 \mathrm{~min}$. Polyclonal anti-Cap1p (a kind gift from Prof. Scott Rowley, University of Iowa, USA) was used at a dilution of 1/500 in blocking solution $(3 \%(\mathrm{w} / \mathrm{v})$ dried skimmed milk powder (Marvel, Dublin, Ireland) and $1 \%(\mathrm{w} / \mathrm{v}) \mathrm{BSA}$ in tris-buffered Saline-tween (TBST) (50 $\mathrm{mM}$ tris- $\mathrm{HCl}, 150 \mathrm{mM}$ sodium chloride (SigmaAldrich), $0.5 \% \quad(\mathrm{v} / \mathrm{v})$ tween 20 (Sigma-Aldrich), $\mathrm{pH}$ 7.6) overnight at room temperature with gentle shaking. Horseradish peroxidase-conjugated donkey anti-rabbit immunoglobulin $\mathrm{G}(\operatorname{IgG})$ (1/500 in blocking solution, G.E. Healthcare Ltd., Buckinghamshire, England.) for 
3 hours with gentle shaking was used to detect reactive bands with the enhanced chemiluminescence system (Pierce Biotechnology Inc., Rockford, IL, USA).

A monoclonal antibody against Phospho-p38 MAPK (Thr180/Tyr182) (mammalian orthologue of yeast HOG kinase) (Cell Signalling Technology Inc., MA, USA) was used at a concentration of 1/500 in blocking solution overnight with gentle shaking at room temperature. Horseradish peroxidase-conjugated anti-mouse immunoglobulin $\mathrm{G}$ (IgG) (1/500 in blocking solution, Cell Signalling Technology Inc.) for $2 \mathrm{~h}$ was used to detect reactive bands with the enhanced chemiluminescence system.

\section{Confocal microscopy}

Cells were exposed to caspofungin $(0.19 \mu \mathrm{g} / \mathrm{ml})$ for $4 \mathrm{~h}$ and harvested as described. The pellet was resuspended in PBS containing 3.7\% (v/v) formaldehyde (Sigma-Aldrich) for $1.5 \mathrm{~h}$ at $30^{\circ} \mathrm{C}$ with gentle shaking. Fixed cells were washed and spotted onto glass slides and allowed to air dry overnight. The samples were permeabilized with $0.1 \%$ (v/v) triton X-100 (BDH, Poole, England) by placing $100 \mu \mathrm{l}$ over the slides and leaving at room temperature for $5 \mathrm{~min}$. Slides were washed by gently dipping into sterile PBS. Slides were placed in a humid chamber and anti-Caplp primary antibody (1/125 in blocking solution, $200 \mu \mathrm{l})$ was placed onto the cells for $4 \mathrm{~h}$. Slides were washed with PBS and tetramethyl rhodamine iso-thiocyanate (TRITCI) goat anti rabbit IgG (Jackson ImmunoResearch Europe Ltd., U.K.), (1/125 in blocking solution, $200 \mu \mathrm{l})$ secondary antibody was placed on the cells and left overnight at $4^{\circ} \mathrm{C}$. Cover slips were applied and sealed and the slides were viewed using an Olympus Fluoview FV1000 confocal microscope.

\section{RNA extraction and RT-PCR analysis}

Candida albicans mRNA was extracted using a Qiagen RNAeasy ${ }^{\circledR}$ (Sussex, England) kit from early exponential phase cells $\left(2.5 \times 10^{6}\right)$ exposed to hydrogen peroxide $(0.5$ $\mathrm{mM})$ or caspofungin $(0.19 \mu \mathrm{g} / \mathrm{ml})$ for $0.5,1,2$, or 4 hours and cDNA was generated using the Superscript III FirstStrand Synthesis System (Invitrogen, CA, USA.) with oligo (dT) primers. PCR amplification of glutathione reductase (GLRI), mitochondrial processing protease (MAS1) and manganese-superoxide dismutase (SOD2) genes was performed using previously described primers [15] and the following cycle conditions: $98^{\circ} \mathrm{C}$ for $2 \mathrm{~min}$, $\left(94^{\circ} \mathrm{C}\right.$ for $1 \mathrm{~min}, 55^{\circ} \mathrm{C}$ for $1 \mathrm{~min}, 68^{\circ} \mathrm{C}$ for $1 \mathrm{~min}$ and 20 $\mathrm{sec}) \times 35$ cycles and $68^{\circ} \mathrm{C}$ for $7 \mathrm{~min}$. Sequences for catalase $(C A T 1)$ and alkyl hydroperoxide reductase (AHPl) were located on the Candida Genome Database at http://www. candidagenome.org/ and primers were designed using the primer 3 program at: http://frodo.wi.mit.edu/. The primer sequences were as follows: CATI-F: GCCGAAGCTAAAGAAGCTGA and CATI-R: TTGCAAGACTGGATCAGCAG, AHPl-F: AAAGACAAGGGCGTCAAAAA and AHP1-R: CTGCCAGAGTCAAATCAGCA. Cycle conditions were as follows: $95^{\circ} \mathrm{C}$ for $5 \mathrm{~min},\left(95^{\circ} \mathrm{C}\right.$ for $30 \mathrm{sec}$, $58.8^{\circ} \mathrm{C}$ for $40 \mathrm{sec}, 68^{\circ} \mathrm{C}$ for $\left.40 \mathrm{sec}\right) \times 33$ cycles and $68^{\circ} \mathrm{C}$ for $7 \mathrm{~min}$. Visualization of amplified products was performed using a Syngene Geneflash and densitometric analysis was carried out using Genetools software.

\section{Enzymatic activity assays}

Candida albicans cells were exposed to caspofungin $(0.19 \mu \mathrm{g} / \mathrm{ml})$ for 1,2 or $4 \mathrm{~h}$ or to hydrogen peroxide $(0.5$ $\mathrm{mM})$ for $30 \mathrm{~min}$. Cells (1 $\mathrm{g}$ wet weight) were harvested, washed in PBS and resuspended in $4 \mathrm{ml}$ of lysing buffer (4 ml Tris- $\mathrm{HCl}$ (100 mM, pH 7.5); $4 \mathrm{ml}$ EDTA (1mM, Sigma-Aldrich); $100 \mu \mathrm{l}$ Pepstatin A $(1 \mathrm{mg} / \mathrm{ml}$, added fresh); $100 \mu \mathrm{l}$ Aprotinin (1 mg/ml, added fresh); $100 \mu \mathrm{l}$ PMSF ( $1 \mathrm{mM}$, added fresh) and $5 \mathrm{mM}$ DTT (added fresh). To this, $4 \mathrm{~g}$ of acid washed glass beads (size: 425 $600 \mu \mathrm{m}$, Sigma-Aldrich) were added. The mixture was vortexed for $5 \mathrm{~min}$ on ice. Cellular debris, broken cell walls and remaining glass beads were removed by centrifugation $\left(250 \mathrm{~g}\right.$ for $5 \mathrm{~min}$ at $4^{\circ} \mathrm{C}$, Eppendorf centrifuge $5417 \mathrm{R})$. The pellets were discarded and the supernanant was used.

For analysis of superoxide dismutase activity the SOD Assay Kit from Fluka (Biochemika) was used in accordance with manufacturer's instructions, using a concentration of $1 \mu \mathrm{g} / \mu \mathrm{l}$ of protein extract. The SOD activity was calculated by employing a tetrazolium salt, WST-1 that produces a water-soluble formazan dye upon reduction with a superoxide anion. The absorbance at $450 \mathrm{~nm}$ was read using a microplate reader (Synergy HT, Bio-Tek) and the following formula was employed to determine SOD activity:

\section{SOD Activity}

$$
=\frac{\left[\left(\mathrm{A}_{\text {blank1 } 1}-\mathrm{A}_{\text {blank3 }}\right)-\left(\mathrm{A}_{\text {sample }}-\mathrm{A}_{\text {blank } 2}\right)\right] \times 100}{\left[\left(\mathrm{~A}_{\text {blank } 1}-\mathrm{A}_{\text {blank }}\right)\right]}
$$

For analysis of the glutathione reductase activity of cells the method described previously [20] was used. The assay used the extinction coefficient $\left(\varepsilon^{\mathrm{mM}}\right)$ of $6.22 \mathrm{mM} / \mathrm{cm}$ for $\mathrm{NADPH}$. Briefly, fresh protein extracts were prepared as above. The following were placed into a clean $1 \mathrm{ml}$ quartz cuvette: $500 \mu \mathrm{l}$ of $2 \mathrm{mM}$ oxidized glutathione (SigmaAldrich), $400 \mu \mathrm{l}$ of assay buffer ( $1 \mathrm{mM}$ EDTA, $100 \mathrm{mM}$ potassium phosphate (Sigma-Aldrich), $\mathrm{pH} 7.5), 50 \mu \mathrm{l}$ protein extract $(1 \mu \mathrm{g} / \mu \mathrm{l})$ and $50 \mu \mathrm{l}$ of $2 \mathrm{mM} \mathrm{NADPH}$ (Sigma-Aldrich)). A blank was prepared consisting of all 
the above except $450 \mu \mathrm{l}$ assay buffer was used and no sample protein was added. The absorbances were read at $340 \mathrm{~nm}$ for $2 \mathrm{~min}$ at $20 \mathrm{sec}$ intervals (Cary varian UVVisible Spectrophotometer). The GLR activity was calculated using the following equation: cellular protein was extracted and fractionated into nuclear and cytoplasmic components. The nuclear protein fraction was resolved by 1-dimensional SDS-PAGE, blotted and probed with anti-Cap1p antibody to verify its presence in the nuclear fraction and its purity. The results demonstrate

GLR $($ units $/ \mu \mathrm{l})=\frac{(\text { Rate of change of sample }- \text { Rate of change of blank })}{6.22 \mathrm{mM} / \mathrm{cm} \times \text { Concentration of protein }(\mu \mathrm{g} / \mu \mathrm{l})}$

Catalase activity was measured as described [21] with slight modifications. Briefly, fresh protein extracts were prepared as stated. Protein extract $(100 \mu \mathrm{l}, 7 \mathrm{mg} / \mathrm{ml})$ was added to $1.8 \mathrm{ml}$ of $17 \mathrm{mM} \mathrm{H} \mathrm{O}_{2}$ in a sterile tube. The mixture was mixed well by pipetting and left at room temperature for 15 minutes. After this time, the suspension was centrifuged at 10,000 $g$ (Eppendorf centrifuge 5417R) for $1 \mathrm{~min}$ to stop the reaction. The supernatant was removed and placed in a clean quartz cuvette. The absorbance at 240 $\mathrm{nm}$ was obtained on a Beckman DU640 spectrophotometer. A blank consisted of $17 \mathrm{mM} \mathrm{H}_{2} \mathrm{O}_{2}$.

\section{Microdilution assay}

Stationary phase cells of $C$. albicans $\left(5 \times 10^{6} / \mathrm{ml}\right)$ were harvested as before. Cells were either exposed to $\mathrm{H}_{2} \mathrm{O}_{2}(0.5$ $\mathrm{mM}$ ) for $60 \mathrm{~min}$ or untreated, and resuspended in YEPD medium. The cell suspension $(100 \mu \mathrm{l})$ was added to each well of a 96-well plate containing various concentrations of Caspofungin $(1-0.003 \mu \mathrm{g} / \mathrm{ml})$ in $100 \mu \mathrm{l}$ of YEPD. The plate was incubated at $30^{\circ} \mathrm{C}$ for $24 \mathrm{~h}$. The optical density was read at $540 \mathrm{~nm}$ using a microplate reader. Growth was quantified as a percentage of control.

\section{Statistical analysis}

All experiments were performed on three independent occasions. Results presented are the mean \pm standard error. A 1-tailed, 2-sample equal variance Student's $t$-test was performed and samples with a $P$ value $\leq 0.05$ were deemed significant.

\section{Results}

\section{Caspofungin treatment induces translocation of Cap I}

The AP-1-like transcription factor Cap1p in C. albicans is involved in the response to oxidative stress [22] and Cap1p function has been shown to be regulated by a nuclear localization mechanism [14]. Oxidant regulated translocation of this transcription factor is also required for tolerance to hydrogen peroxide and for diamide detoxification in C. albicans [14]. C. albicans cells were exposed to $0.19 \mu \mathrm{g} / \mathrm{ml}$ caspofungin for 1,2 and $4 \mathrm{~h}$ at $30^{\circ} \mathrm{C}$, after which time
(Fig. 1) that exposure of C. albicans to caspofungin for a period of $2 \mathrm{~h}$ increased the amount of Cap1p in the nuclear fraction by approximately 3 fold relative to the control $(P<0.05)$.

The translocation of Cap1p from the cytoplasm to the nucleus was also visualized using confocal microscopy. In this case, cells were exposed to caspofungin or hydrogen peroxide, fixed, permeabilsed and exposed to anti-Cap1p antibody (as described). The control cells show an even distribution of fluorescence, indicating the presence of the Cap1 protein throughout the cytoplasm (Fig. 2A). Following exposure to $0.5 \mathrm{mM}$ hydrogen peroxide for $30 \mathrm{~min}$,

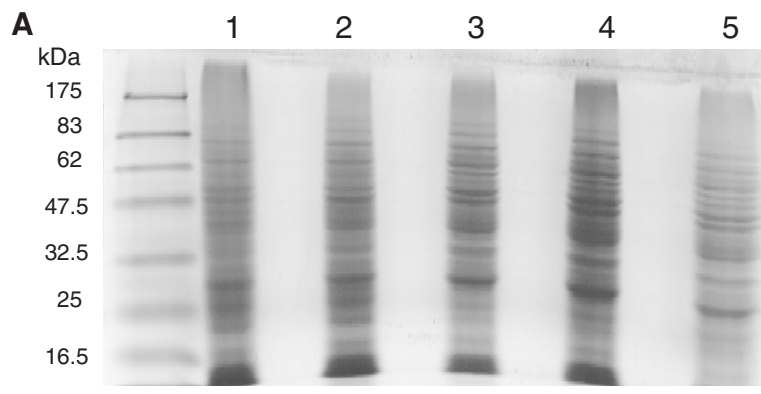

\section{B $\quad 65 \mathrm{kDa}$}

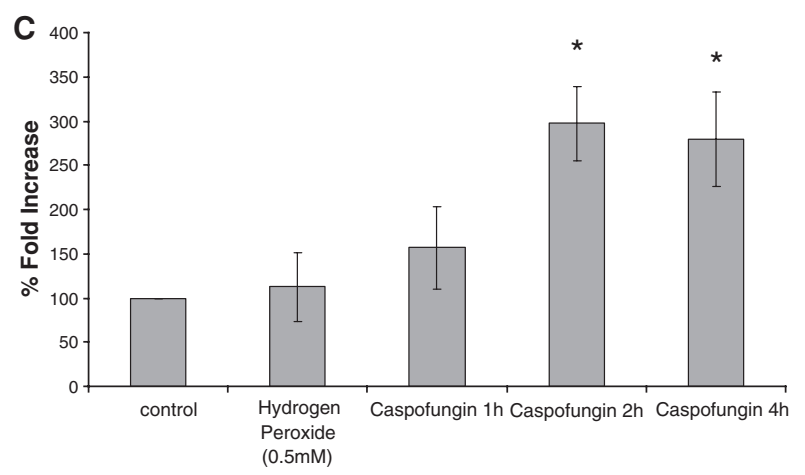

Fig. 1 Exposure of Candida albicans to caspofungin causes nuclear translocation of Cap1p. (A) SDS PAGE gel of nuclear proteins stained with Coomassie blue. Lane 1: untreated, Lane 2: $0.5 \mathrm{mM} \mathrm{H}_{2} \mathrm{O}_{2}$ for 30 min, Lane 3: $0.19 \mu \mathrm{g} / \mathrm{ml}$ caspofungin for $1 \mathrm{~h}$, Lane 4: $0.19 \mu \mathrm{g} / \mathrm{ml}$ caspofungin for $2 \mathrm{~h}$, Lane 5: $0.19 \mu \mathrm{g} / \mathrm{ml}$ caspofungin for $4 \mathrm{~h}$. (B) Western blot probed with anti-Cap1p, and (C) Densitometric analysis of Western blot $\left({ }^{*} P<0.05\right)$. 
A

Hydrogen

Peroxide

$(0.5 \mathrm{mM}$, $30 \mathrm{~min})$

\section{C}

Caspofungin $(0.19 \mu \mathrm{g} / \mathrm{ml})$

(4h)
Control
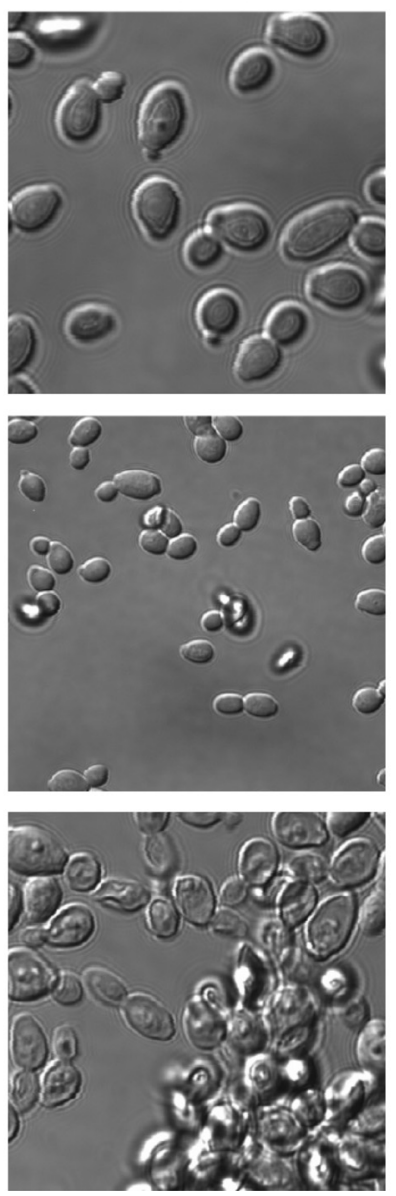

TRITCI
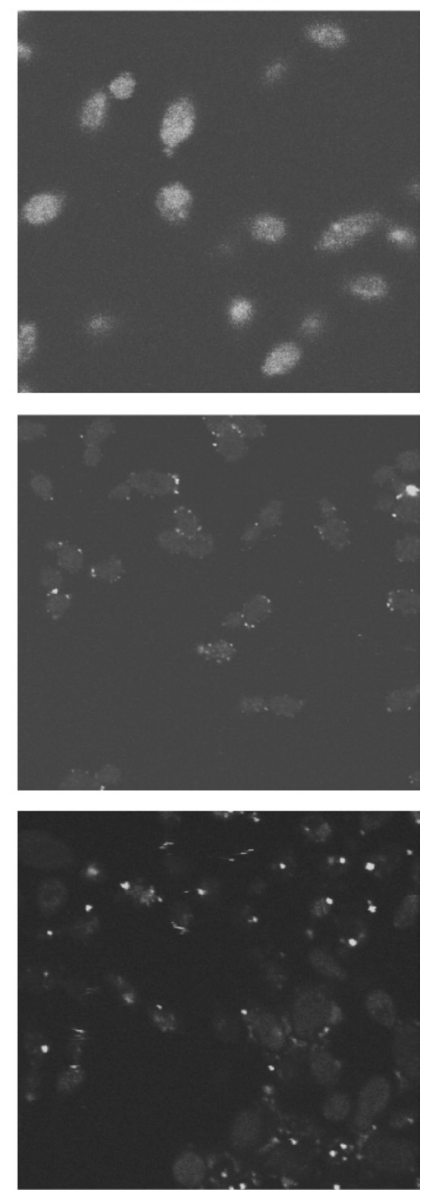

Fig. 2 Visualization of nuclear localization of Cap1p in Candida albicans treated with hydrogen peroxide (0.5 $\mathrm{mM}, 30 \mathrm{mins})$ or caspofungin $(0.19 \mu \mathrm{g} / \mathrm{ml}$ caspofungin $4 \mathrm{~h}$ ). TRITCI labelled anti-rabbit IgG bound to Cap1p, viewed by confocal microscopy (High Power). fluorescence is concentrated in discrete areas within the cell which are coincident with the nucleus indicating translocation of Cap1p (Fig. 2B). A similar situation is evident in caspofungin treated cells which show strong fluorescence in discrete regions of the cell corresponding to the nucleus (Fig. 2C).

These results indicate that hydrogen peroxide and caspofungin induce translocation of Cap1p to the nucleus and that this event can be verified by Western blot and confocal microscopy.

\section{Induction of Cap Ip associated genes}

Translocation of the Cap1 protein to the nucleus induces a number of genes involved in the cell's response to oxidative stress $[14,15]$. In this work RT-PCR analysis was performed on cells exposed to caspofungin and the induction of genes for glutathione reductase (GLR1), superoxide dismutase (SOD2) and mitochondrial processing protease (MAS1) was observed (Fig. 3). In the case of GLRl, maximum induction was visible in cells exposed to caspofungin for $2 \mathrm{~h}(P<0.05)$, while in the case of SOD2, the maximum induction occurred at $1 \mathrm{~h}(P<0.05)$. The highest level of $M A S 1$ induction was recorded at $2 \mathrm{~h}$ in cells exposed to caspofungin $(P<0.05)$. Exposure of cells to hydrogen peroxide induced GLRI (1.66 fold increase after $30 \mathrm{~min}$, $P<0.05)$ but not SOD2 and MAS1.

The data presented here demonstrate that upon exposure to caspofungin there is an increase in the amount of Cap1p in the nuclear fraction and a corresponding induction of a number of genes known to be associated with detoxifying the cell during periods of oxidative stress $[14,15]$.

\section{Determination of alterations in enzyme activities}

The demonstration of the induction of a number of genes associated with oxidative stress following exposure to caspofungin lead to an investigation of the activities of superoxide dismutase and glutathione reductase which have well established cellular detoxifying properties. Glutathione reductase is required for the recycling of oxidized glutathione to its reduced form and the glutathione 
A
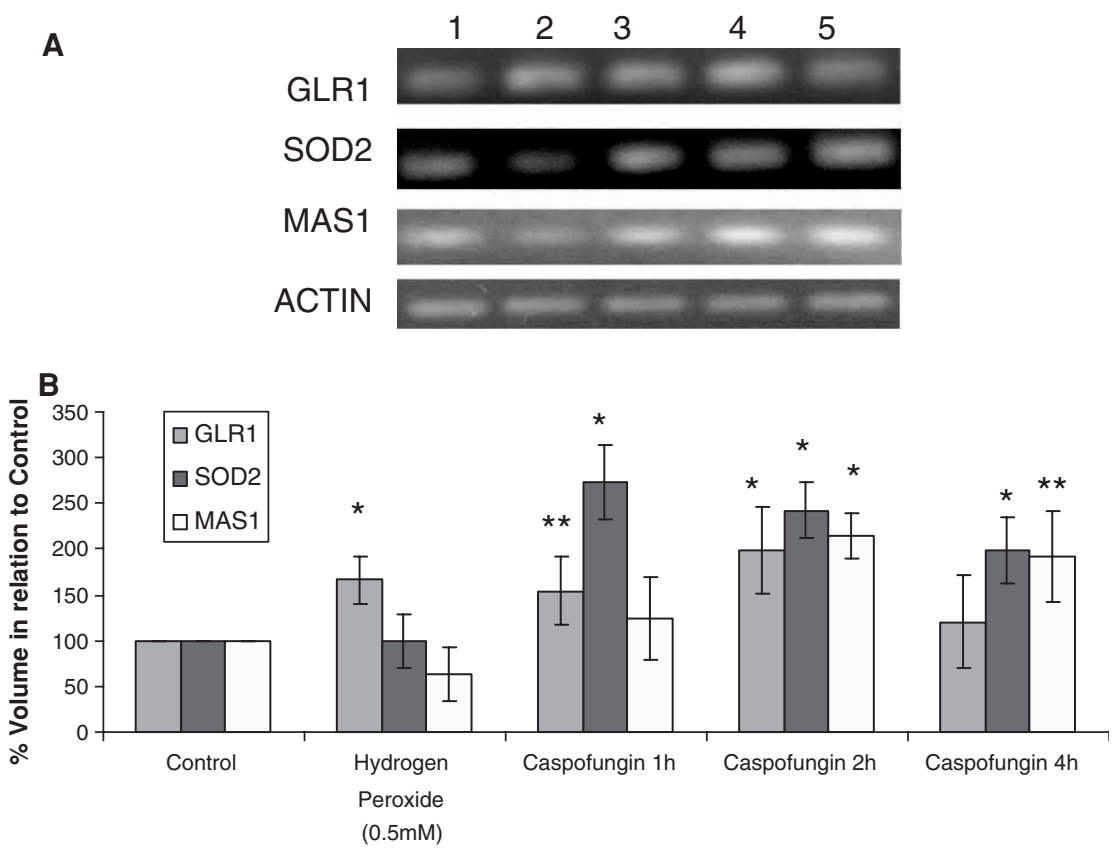

Fig. 3 mRNA levels of genes activated upon Cap1p translocation. (A) RT-PCR analysis of GLR1, SOD2 and MAS1. Lane 1: untreated cells; Lane 2: $\mathrm{H}_{2} \mathrm{O}_{2}(30 \mathrm{~min})$; Lane 3: $0.19 \mu \mathrm{g} / \mathrm{ml}$ caspofungin for $1 \mathrm{~h} ;$ Lane $4: 0.19 \mu \mathrm{g} / \mathrm{ml}$ caspofungin for $2 \mathrm{~h}$; Lane 5: $0.19 \mu \mathrm{g} / \mathrm{ml}$ caspofungin for $4 \mathrm{~h}$. (B) Densitometric analysis of GLR1, SOD2 and MAS1 expression ( $\left.{ }^{*} P<0.05,{ }^{* *} P<0.1\right)$. reductase activity of caspofungin treated cells was measured as described. At all time points tested, it was evident that caspofungin caused an increase in glutathione reductase activity $(P<0.05)$ compared to the control (Fig. 4A). It is noticeable that following exposure to caspofungin for $1 \mathrm{~h}$ there is a dramatic increase in activity but that this has declined by 120 and $240 \mathrm{~min}$. Hydrogen peroxide was used as a positive control and this also increased glutathione reductase activity after $30 \min (P<0.05)$.

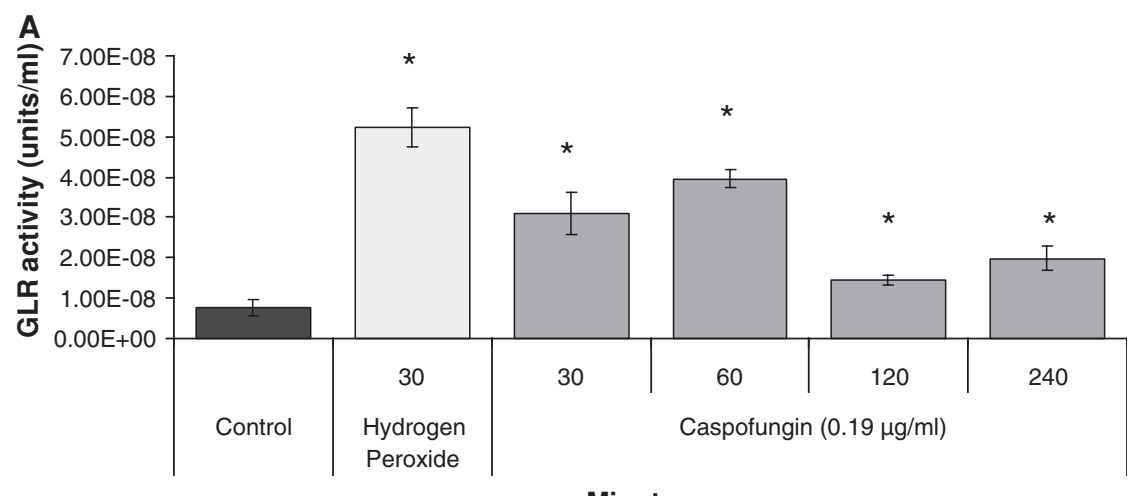

Minutes

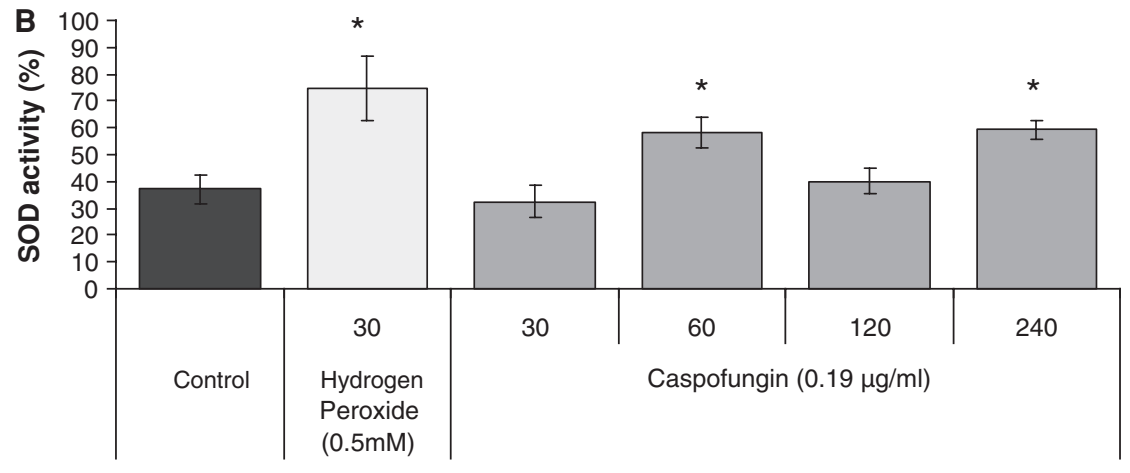

Minutes
Fig. 4 Activity of (A) glutathione reductase and (B) superoxide dismutase following exposure of Candida albicans to caspofungin. Cells were exposed to hydrogen peroxide for 30 min as a positive control, or caspofungin ( 0.19 $\mu \mathrm{g} / \mathrm{ml}$ ) for the periods indicated. Enzymatic activities were determined as described $\left({ }^{*} \mathrm{P}<0.05\right)$.

(C) 2009 ISHAM, Medical Mycology, 47, 697-706 
Superoxide dismutase is an anti-oxidant enzyme and it catalyses the dismutation of superoxide radical anions into dioxygen and hydrogen peroxide. SOD activity was measured and it was found to be greater in caspofungin treated cells compared to the control (Fig. 4B). Activity was highest at 1 and 4 hours upon exposure to caspofungin. Hydrogen peroxide was employed as a positive control and this greatly increased SOD activity after $30 \min (P<0.05)$.

\section{Caspofungin treatment induces translocation of $\mathrm{Hog}$}

The Hog MAP kinase pathway has been demonstrated to be activated in response to exposure of yeast to oxidative stress and C. albicans cells that are deficient in the Hog MAP kinase exhibit increased sensitivity to agents that generate oxidative stress [16]. C. albicans cells were exposed to $0.19 \mu \mathrm{g} / \mathrm{ml}$ caspofungin for 1,2 and $4 \mathrm{~h}$ after which time whole cell protein was extracted and fractionated into nuclear and cytoplasmic components. The nuclear protein portion was resolved by 1-dimensional SDS-PAGE, blotted and probed with phospho-p38 MAPK (Thr180/ Tyr182) monoclonal antibody (Fig. 5). The results indicate that upon exposure to caspofungin, levels of Hog $1 \mathrm{p}$ within the nucleus are elevated approximately 2 fold at 1 and

A
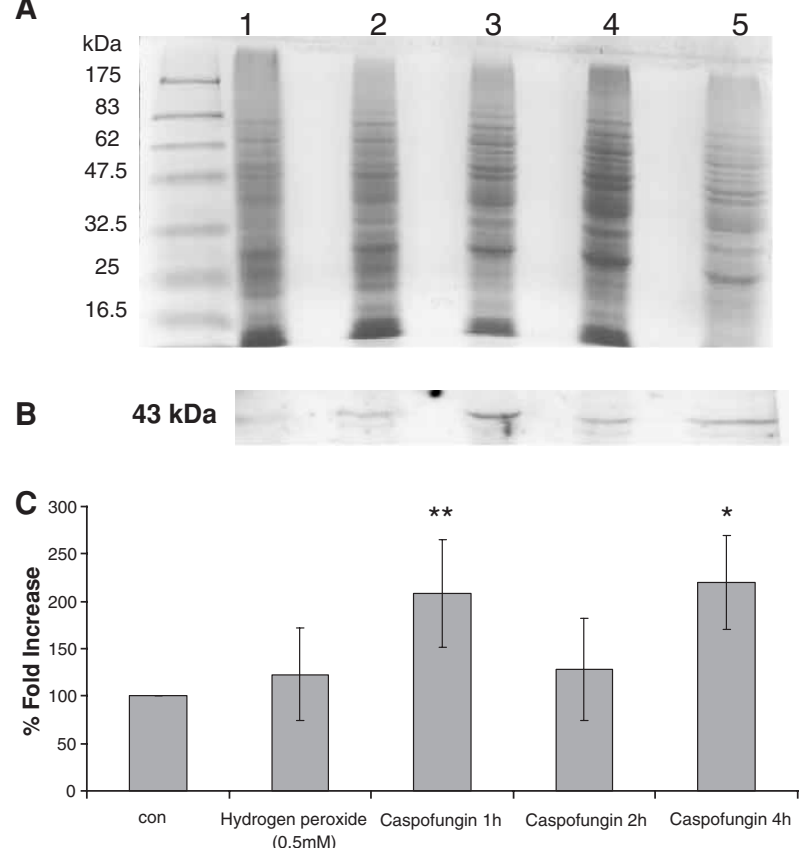

Fig. 5 Exposure of Candida albicans to caspofungin induces nuclear translocation of Hog 1p. (A) SDS PAGE gel of nuclear proteins stained with Coomassie blue. Lane 1: untreated, Lane 2: $0.5 \mathrm{mM} \mathrm{H}_{2} \mathrm{O}_{2}$ for $30 \mathrm{~min}$, Lane 3: $0.19 \mu \mathrm{g} / \mathrm{ml}$ caspofungin for $1 \mathrm{~h}$, Lane $4: 0.19 \mu \mathrm{g} / \mathrm{ml}$ caspofungin for $2 \mathrm{~h}$, Lane 5: $0.19 \mu \mathrm{g} / \mathrm{ml}$ caspofungin for $4 \mathrm{~h}$. B. Western blot probed with anti-phospho-p38 MAPK (Thr180/Tyr182), and (C) Densitometric analysis of Western blot $\left({ }^{*} P<0.05,{ }^{* * *} P<0.1\right)$.
4 hours $(P<0.05)$ compared to the control. Hydrogen peroxide was used as a positive control and induced a small increase in nuclear associated Hog $1 \mathrm{p}$ at $30 \mathrm{~min}$.

\section{Analysis of expression of Hog I associated genes}

The translocation of Hog $1 \mathrm{p}$ to the nucleus has been shown to induce a number of genes involved in the cell's ability to counteract oxidative and osmotic stress [19,23,24,28]. Cells exposed to caspofungin were examined for the induction of catalase (CATI) and alkyl hydroperoxide reductase $(A H P 1)$ which have been shown to be induced in a Hog dependent manner $[23,25,26]$. The results obtained using RT-PCR to examine gene induction (Fig. 6) demonstrate the induction of $C A T 1$ following $1 \mathrm{~h}$ exposure to caspofungin by approximately 1.7 fold compared to the control. In contrast there is no statistically significant induction of $A H P 1$ at any of the time points.

\section{Catalase activity in caspofungin treated cells}

Catalase exhibits important antioxidant properties by catalyzing the decomposition of hydrogen peroxide into water and oxygen. Assessment of the enzymatic activity of catalase in cells exposed to caspofungin indicated a dramatic increase in activity following exposure to this compound for $1 \mathrm{~h}(P<0.05)$ (Fig. 7). Activity reached a peak at $2 \mathrm{~h}$ and then declined. Hydrogen peroxide treatment was employed a positive control, and it increased catalase activity following exposure for $30 \mathrm{~min}(P<0.05)$.

A
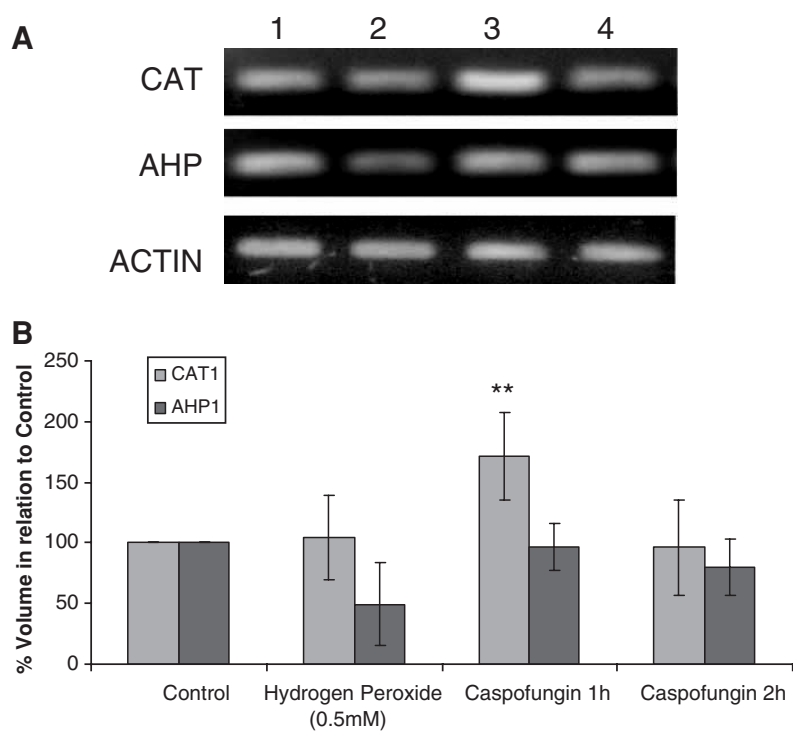

Fig. 6 mRNA levels of genes activated upon Hog1p translocation. (A) RT-PCR analysis of CAT1 and AHP1. Lane 1: untreated cells; Lane 2: $\mathrm{H}_{2} \mathrm{O}_{2}$ (30 min); Lane 3: $0.19 \mu \mathrm{g} / \mathrm{ml}$ caspofungin for $1 \mathrm{~h}$; Lane 4: $0.19 \mu \mathrm{g} / \mathrm{ml}$ caspofungin for $2 \mathrm{~h}$. (B) Densitometry analysis of CAT1 and AHPl expression $\left({ }^{* *} P<0.1\right)$. 


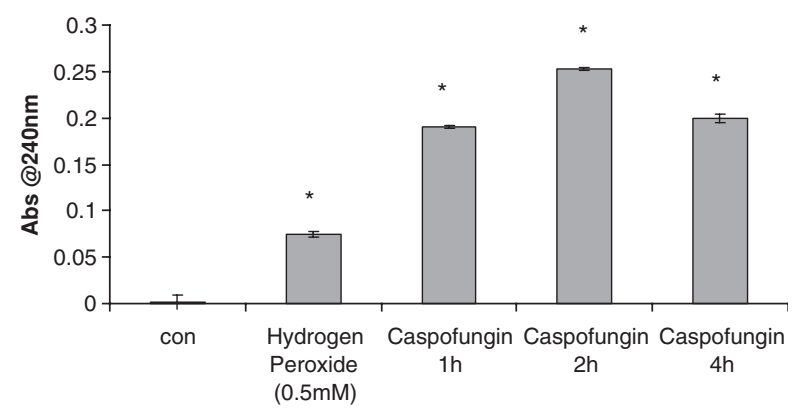

Fig. 7 Exposure of Candida albicans to caspofungin leads to increased catalase activity. Cells were treated with $\mathrm{H}_{2} \mathrm{O}_{2}$ or caspofungin for 1,2 or $4 \mathrm{~h}$ and the catalase activity was determined as described $\left({ }^{*} \mathrm{P}<0.05\right)$.

Prior exposure to hydrogen peroxide increases the tolerance of $C$. albicans to caspofungin

Hydrogen peroxide $(0.5 \mathrm{mM}, 60 \mathrm{~min})$ treated cells were subsequently exposed to caspofungin (1-0.003 $\mu \mathrm{g} / \mathrm{ml}$ ), incubated for $24 \mathrm{~h}$ and the growth was measured spectrophotometrically at $540 \mathrm{~nm}$. The results (Fig. 8) show an increase in growth of hydrogen peroxide treated cells compared to untreated cells, with a 3-fold increase in growth at $0.015 \mu \mathrm{g} / \mathrm{ml}$ caspofungin in $\mathrm{H}_{2} \mathrm{O}_{2}$ treated cells compared to untreated cells $(P<0.05)$. Previous results have demonstrated that exposure to hydrogen peroxide activates an oxidative response in C. albicans (Figs. 1 and 2). Short term exposure to hydrogen peroxide leads to increased growth in the presence of caspofungin possibly as a result of the activation of the oxidative stress response by hydrogen peroxide.

\section{Discussion}

The echinocandin drug caspofungin is well tolerated in humans and has become an established element of the

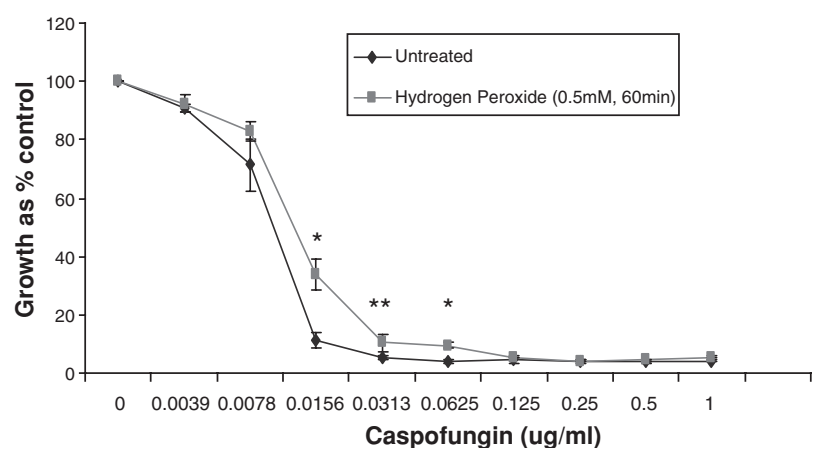

Fig. 8 Elevated growth of Candida albicans in caspofungin following prior exposure to hydrogen peroxide. Cells were exposed to $0.5 \mathrm{mM}$ hydrogen peroxide for $60 \mathrm{~min}$, harvested by centrifugation, washed and then resuspended in wells of 96-well microdilution plates containing a gradient of caspofungin concentrations (as described). Growth was measured at $540 \mathrm{~nm}\left({ }^{*} \mathrm{P}<0.05,{ }^{* *} \mathrm{P}<0.1\right)$. antifungal armamentarium [12]. It has found applications in the treatment of infections by Candida and Aspergillus spp. and its safety profile makes it an attractive alternative to the use of amphotericin B in appropriate cases. The results presented here demonstrate that upon exposure to caspofungin, $C$. albicans activates two distinct pathways (Cap and Hog) which are designed to combat oxidative and osmotic stresses.

Exposure of $C$. albicans to caspofungin resulted in the nuclear localization of Cap1p which was visualized by Western blotting and also by confocal microscopy using TRITCI labeled IgG bound to Cap1p. The increase in nuclear Cap1p following exposure to caspofungin for $2 \mathrm{~h}$ was approximately 3 fold. This translocation event was evident in Fig. 2 where the concentration of the transcription factor in the nucleus is demonstrated.

Upon translocation to the nucleus, Cap1p activates a number of genes that form an important component of the cell's response to stress [15]. In this work, the induction of three genes was monitored (Fig. 3) and the results indicated induction of SOD2 at 1, 2 and $4 \mathrm{~h}$ and the induction of MAS1 at 2 and $4 \mathrm{~h}$. The induction of GLR1 was only evident at $2 \mathrm{~h}$. Together with this, an increase in the activity of superoxide dismutase and glutathione reductase was observed (Fig. $4 \mathrm{~A}$ and B).

A number of genes are activated in response to Hog1 activation in order to assist in the protection of the cell [24,26-28]. C. albicans cells that are deficient in the Hog1 MAP kinase exhibit increased sensitivity to agents that generate oxidative stress [16]. Nuclear localization of Hog $1 \mathrm{p}$ was demonstrated following caspofungin treatment (Fig. 5) and the induction of CATl and AHPl (Fig. 6) was analysed. The increased expression of CAT1 was evident at $1 \mathrm{~h}$ however the expression of AHP1 did not appear to alter during the course of the experiment. In parallel with the induction of the CATl gene, there was also a dramatic increase in the activity of catalase which peaked at $2 \mathrm{~h}$ following caspofungin exposure (Fig. 7).

Reactive oxygen species (ROS) are a normal by-product of respiration; however sources of ROS may also be external. If levels of ROS become high and if not adequately eliminated from the cell, this can lead to oxidation of proteins and nucleic acids which in turn can inactivate enzymes leading to cell death. The activation of the enzymes controlled by the Cap and Hog pathways give vital protective abilities to the cell to withstand stress [14-16,27].

We sought to establish whether the activation of the Cap1 and Hog pathways could protect the cell against subsequent caspofungin exposure. Hydrogen peroxide is a well established activator of the Cap1 pathway [14,15] and this compound was used to pre-treat cells at a low concentration for a short period of time. Following exposure to $0.5 \mathrm{mM}$ hydrogen peroxide for $60 \mathrm{~min}$ cells were 
exposed to caspofungin and growth was quantified after $24 \mathrm{~h}$. The results demonstrate that pre-treatment with hydrogen peroxide lead to an increase in growth in the presence of caspofungin (Fig. 8) and notably gave a 3-fold increase in tolerance to $0.01 \mu \mathrm{g} / \mathrm{ml}$ caspofungin compared to the untreated control. This increase in growth is presumably a result of the activation of the responses to combat the oxidative and osmotic stresses prior to exposure to caspofungin. These data may have clinical implications since oxidative stress is employed in the neutrophil-mediated killing of microbial cells [29] and this stress could 'prime' cells to subsequent caspofungin exposure thus necessitating a higher dose of the antifungal to achieve cell death.

Exposure of C. albicans to caspofungin has been shown to unmask $\beta$-glucan which is highly immunogenic and induces a stronger immune response [30]. The data presented here demonstrate that exposure of $C$. albicans to caspofungin leads to the rapid activation of both the Cap1 and Hog pathways. The activation of these responses gives the cell the ability to protect itself from the osmotic and oxidative stress induced by this antifungal drug. It is postulated that caspofungin causes the cell to become sensitive to osmotic stress, due to a disruption in cell wall formation, leading to eventual cell death by lysis. Prior activation of an oxidative stress response facilitates increased growth in the presence of caspofungin indicating a possible role for oxidative stress altering the sensitivity of $C$. albicans to this agent in vivo.

\section{Acknowledgements}

This work was supported by funding from the Higher Education Authority of Ireland through the Programmes for Research in Third Level Institutes 3 and 4. The authors acknowledge the technical assistance of Dr Ica Dix in obtaining Confocal microscopy images.

Declaration of interest: The authors report no conflicts of interest. The authors alone are responsible for the content and writing of the paper.

\section{References}

1 Wisplinghoff H, Bischoff T, Tallent SM, et al. Nosocomial bloodstream infections in US hospitals: Analysis of 24,179 cases from a prospective nationwide surveillance study. Clin Infect Dis 2004; 39: 309-317.

2 Deresinski S, Stevens DA. Caspofungin. Clin Infect Dis 2003; 36: 1445-1457.

3 Maertens J, Raad I, Petrikkos G, et al. Efficacy and safety of caspofungin for treatment of invasive aspergillosis in patients refractory to or intolerant of conventional antifungal therapy. Clin Infect Dis 2004; 39: 1563-1571.

C 2009 ISHAM, Medical Mycology, 47, 697-706
4 Sarria JC, Bradley JC, Habash R, et al. Candida glabrata endophthalmitis treated successfully with caspofungin. Clin Infect Dis 2005; 40 e46-8.

5 Soustre J, Rodier MH, Imbert-Bouyer S, et al. Caspofungin modulates in vitro adherence of Candida albicans to plastic coated with extracellular matrix proteins. J Antimicrob Chemother 2004; 53: 522-525.

6 Betts R, Glasmacher A, Maertens J, et al. Efficacy of caspofungin against Candida or invasive Aspergillus infections in neutropenic patients. Cancer 2006; 106: 466-473.

7 Rajendram R, Alp NJ, Mitchell AR, et al. Candida prosthetic valve endocarditis cured by caspofungin therapy without valve replacement. Clin Infect Dis 2005; 40: e72-4.

8 Walsh TJ, Teppler H, Donowitz GR, et al. Caspofungin versus liposomal amphotericin B for empirical antifungal therapy in patients with persistent fever and neutropenia. $N$ Engl J Med 2004; 351: 1391-1402.

9 Abruzzo GK, Gill CJ, Flattery AM, et al. Efficacy of the echinocandin caspofungin against disseminated aspergillosis and candidiasis in cyclophosphamide-induced immunosuppressed mice. Antimicrob Agents Chemother 2000; 44: 2310-2318.

10 Bachmann SP, Patterson TF, López-Ribot JL. In vitro activity of caspofungin (MK-0991) against Candida albicans clinical isolates displaying different mechanisms of azole resistance. J Clin Microbiol 2002; 40: 2228-2230.

11 Petraitiene R, Petraitis V, Groll AH, et al. Antifungal efficacy of caspofungin (MK-0991) in experimental pulmonary aspergillosis in persistently neutropenic rabbits: pharmacokinetics, drug disposition, and relationship to galactomannan antigenemia. Antimicrob Agents Chemother 2002; 46: 12-23.

12 Denning DW. Echinocandin antifungal drugs. Lancet 2003; 362 1142-1151.

13 Busch SJ, Sassone-Corsi P. Dimers, leucine zippers and DNA-binding domains. Trends Genet 1990; 6: 36-40.

14 Zhang X, De Micheli M, Coleman ST, Sanglard D, Moye-Rowley WS. Analysis of the oxidative stress regulation of the Candida albicans transcription factor, Cap1p. Mol Microbiol 2000; 36: 618-629.

15 Wang Y, Cao YY, Jia XM, et al. Cap1p is involved in multiple pathways of oxidative stress response in Candida albicans. Free Radic Biol Med 2006; 40: 1201-1209.

16 Alonso-Monge R, Navarro-García F, Román E, et al. The Hog1 mitogen-activated protein kinase is essential in the oxidative stress response and chlamydospore formation in Candida albicans. Eukaryot Cell 2003; 2: 351-361.

17 Brewster JL, de Valoir T, Dwyer ND, Winter E, Gustin MC. An osmosensing transduction pathway in yeast. Science 1993; 259: $1760-1763$.

18 Saito H, Tatebayashi K. Regulation of the osmoregulatory HOG MAPK cascade in yeast. $J$ Biochem 2004; 136: 267-272.

19 Hohmann S. Osmotic stress signaling and osmoadaptation in yeasts. Microbiol Mol Biol Rev 2002; 66: 300-372.

20 Foster JG, Hess JL. Responses of superoxide dismutase and glutathione reductase activity in cotton leaf tissue to an atmosphere enriched in oxygen. Plant Physiol 1980; 66: 482-487.

21 Larsen B, White S. Antifungal effect of hydrogen peroxide on catalase-producing strains of Candida spp. Infect Dis Obst Gynecol 1995; 3: 73-78.

22 Alarco AM, Raymond M. The bZip Transcription Factor Cap1p is involved in multidrug resistance and oxidative stress response in Candida albicans. J Bacteriol 1999; 181: 700-708.

23 Enjalbert B, Smith DA, Cornell MJ, et al. Role of the Hog1 stressactivated protein kinase in the global transcriptional response to stress in the fungal pathogen Candida albicans. Mol Biol Cell 2006; 17: $1018-1032$. 
24 Ikner A, Shiozaki K. Yeast signaling pathways in the oxidative stress response. Mutat Res 2005; 569: 13-27.

25 Lee J, Spector D, Godon C, Labarre J, Toledano MB. A new antioxidant with alkyl hydroperoxide defense properties in yeast. $J$ Biol Chem 1999; 274: 4537-4544.

26 Schüller C, Brewster JL, Alexander MR, Gustin MC, Ruis H. The HOG pathway controls osmotic regulation of transcription via the stress response element (STRE) of the Saccharomyces cerevisiae CTT1 gene. EMBO J 1994; 13: 4382-4389.

27 Rep M, Krantz M, Thevelein JM, Hohmann S. The transcriptional response of Saccharomyces cerevisiae to osmotic shock. Hot1p and Msn2p/Msn4p are required for the induction of subsets of high osmolarity glycerol pathway-dependent genes. J Biol Chem 2000; 275: 8290-8300.

28 Rep M, Proft M, Remize F, et al. The Saccharomyces cerevisiae Sko1p transcription factor mediates HOG pathway-dependent osmotic regulation of a set of genes encoding enzymes implicated in protection from oxidative damage. Mol Microbiol 2001; 40: 1067-1083.

29 Wymann M, von Tscharner V, Deranleau D, Baggiolini M. Chemiluminescence detection of $\mathrm{H} 2 \mathrm{O} 2$ produced by human neutrophils during the respiratory burst. Anal Biochem 1987; 165: 371-378.

30 Wheeler RT, Fink GR. A drug-sensitive genetic network masks fungi from the immune system. PLoS Pathog 2006; 2: e35. DOI: 10.1371/ journal.ppat.0020035.

This paper was first published online on iFirst on 5 March 2009. 